\title{
Efektivitas Pembelajaran Jarak Jauh Dalam Perspektif Mahasiswa
}

\author{
Hasanuddin ${ }^{1, *}$ \\ ${ }^{1}$ Fakultas Ekonomi dan Bisnis; Universitas Bhayangkara Jakarta Raya; Jl Perjuangan 081, \\ Marga Mulya, Bekasi Utara, 02188955882/ 02188955871; e-mail: \\ hasanuddin@dsn.ubharaajaya.ac.id \\ * Korespondensi: e-mail: hasanuddin@dsn.ubharajaya.ac.id \\ Submitted: 04/01/2022; Revised: 12/01/2022; Accepted: 19/01/2022; Published: 31/01/2022
}

\begin{abstract}
This research was conducted to determine the effectiveness of distance learning from the perspective of students such as the material provided by the lecturer, understanding of the material, obstacles in participating in distance learning, and the learning model carried out. This study uses a descriptive survey method, the research sample is students from Bhayangkara University, Jakarta Jaya (Ubhara Jaya). Data collection techniques using a questionnaire. The findings in this study, $64.1 \%$ of students disagree with distance learning, according to students distance learning is not effective in the teaching and learning process, and $35.9 \%$ agree. Those who agree with distance learning generally state that this is a way to stop the spread of Covid 19. When asked about the understanding of the lecture material delivered by the lecturer through distance learning, 72.5 students found it difficult because the question-and-answer process was less effective. Constraints experienced by students during distance learning, $43.1 \%$ were caused by unstable signals, $37.7 \%$ answered that there were no problems, and $19.2 \%$ answered that they sometimes experienced signal disturbances. Regarding student spending during distance learning, $43.8 \%$ said they were not more efficient than offline lectures, $41.1 \%$ said there were savings.
\end{abstract}

Keywords: Covid-19, Distance Learning, Learning Effectiveness

\begin{abstract}
Abstrak
Penelitian ini dilakukan untuk mengetahui efektivitas pembelajaran jarak jauh dari perspektif mahasiswa seperti materi yang diberikan dosen, pemahaman terhadap materi, kendala dalam mengikuti pembelajaran jarak jauh, dan model pembelajaran yang dilakukan. Penelitian ini menggunakan metode survey deskriptif, sampel penelitian adalah mahasiswa Universitas Bhayangkara Jakarta Jaya (Ubhara Jaya). Teknik pengumpulan data menggunakan kuesioner. Temuan dalam penelitian ini, $64.1 \%$ mahasiswa tidak setuju dengan pembelajaran jarak jauh, menurut mahasiswa pembelajaran jarak jauh tidak efektif dalam proses belajar mengajar, dan 35,9\% menyatakan setuju. Yang setuju dengan pembelajaran jarak jauh secara umum menyatakan bahwa ini cara menghentikan penyebaran Covid 19. Ketika ditanyakan pemahaman terhadap materi kuliah yang disampaikan dosen melalui pembelajaran jarak jauh, 72,5 mahasiswa merasa kesulitan karena proses tanya jawab berlangsung kurang efektif. Kendala yang dialami mahasiswa selama pembelajaran jarak jauh, 43,1\% disebabkan signal yang tidak stabil, 37,7\% menjawab tidak ada kendala, dan 19,2\% menjawab kadang-kadang mengalami gangguan signal. Menyangkut pengeluaran mahasiswa selama pembelajaran jarak jauh, 43,8\% menyatakan tidak lebih hemat jika dibandingkan kuliah offline, 41,1\% menjawab ada penghematan.
\end{abstract}

Kata kunci: Covid-19, Pembelajaran Jarak Jauh, Efektivitas Pembelajaran 


\section{Pendahuluan}

Membaca berbagai laporan media mengenai penyebaran Covid 19 di Indonesia cukup mengkhawatirkan, kenaikannya sangat cepat. Sejak 2 Maret 2020, untuk pertama kalinya pemerintah mengumumkan 2 warga negara Indonesia terdeteksi positif Covid 19, yang disampaikan langsung oleh Presiden RI. Sejak saat itu grafik penularannya terus naik, hingga 2 Oktober 2021, Pemerintah Republik Indonesia melaporkan 4.218.142 orang terkonfirmasi positif COVID 19 dengan jumlah kematian mencapai 142.115 (CFR: 3,4\%) terkait COVID-19 yang dilaporkan, dan 4.042.215 pasien dinyatakan sembuh dari penyakit tersebut. (Kemenkes $\mathrm{Rl}, 2021)$.

Covid 19 yang melanda dunia termasuk Indonesia, merubah pola interaksi pada setiap level aktivitas manusia. Untuk mengurangi interaksi antar manusia, berbagai negara memberlakukan pembatasan keluar masuk manusia ke wilayahnya (lockdown), termasuk Pemerintah Indonesia mengambil kebijakan yang sama walau dengan istilah berbeda yaitu pembatasan sosial berskala besar (PSBB) untuk memutus rantai penyebaran virus.

Perubahan pola interaksi ini juga terjadi pada dunia pendidikan termasuk pada pendidikan tinggi, di mana sebelum Covid 19 proses belajar mengajar dilakukan seperti biasa yakni tatap muka (diruang kelas), namun, sejak Pandemi proses belajar dilakukan dengan pola daring, mahasiswa dan dosen tidak lagi bertemu secara langsung, tapi melalui internet. Pola baru ini dimaksudkan untuk memutus rantai penyebaran Virus Corona.

Epidemolog sepakat bahwa penyebaran Virus Covid 19 terjadi melalui kontak manusia, sehingga harus diputus dengan cara membatasi kontak antar manusia. Untuk mengantisipasi, pemerintah mengambil kebijakan pembatasan sosial berskala besar (PSBB), masyarakat diminta melakukan kegiatan dari rumah termasuk belajar mengajar. Kementerian Pendidikan dan Kebudayaan (Kemendikbud) merespon kebijakan PSBB tersebut dengan mengeluarkan Surat Edaran Nomor 4 Tahun 2020 Tentang Pelaksanaan Pendidikan Dalam Masa Darurat Coronavirus Disease (Covid 19). (Pengelola web kemdikbud, 2020). Memperkuat surat ederan sebelumnya, dikeluarkan lagi Surat Edaran Nomor 15 Tahun 2020 Tentang Pedoman Penyelenggaraan Belajar Dari Rumah Dalam Masa Darurat Penyebaran Covid 19. (Pengelola web Kemdikbud, 2020).

Surat edaran tersebut dibuat untuk memastikan terpenuhinya hak peserta didik mendapatkan pendidikan dan pengajaran selama masa pandemi, menjaga dan melindungi setiap warga serta ekosistem pendidkan agar tidak terpapar virus dan menjadi bagian dari gerakan nasional mencegah penyebaran dan penularan Covid 19. Selain itu, surat edaran tersebut dimaksudkan untuk memberi rasa aman bagi pendidik, peserta didik, dan orang tua. Menindak lanjuti SE Kemendikbud tersebut, Rektor Ubhara Jaya mengambil langkah cepat dengan meliburkan seluruh mahasiswa dan dosen dari kegiatan di Kampus, terhitung mulai hari Senin, 16 Maret 2020 guna menjaga dari kemungkinan terpapar Virus Corona atau Covid 19.

Kebijakan Kemendikbud dan Rektor Ubhara Jaya, belajar dari rumah (daring) merupakan respon untuk memutus rantai penyebaran Covid 19. Pola belajar mengajar yang 
berubah dengan cara daring atau pembelajaran jarak jauh cukup mengagetkan, karena merubah kebiasan lama dari belajar di kelas atau tatap muka ke Pembelajaran Jarak Jauh. Ini bukan hal mudah, oleh karena itu semua pihak yang terlibat dalam proses ini harus mampu menyesuaikan diri dengan cepat. Dosen, mahasiswa, tenaga kependidikan termasuk institusi perguruan tinggi (PT) dituntut memiliki kemampuan adaptif dengan sistem pembelajaran baru yaitu pembelajaran jarak jauh. Dalam pelaksanaan pembelajaran jarak jauh berbagai perangkat pendukung perlu dipersipakan secara baik.

Pembelajaran jarak jauh merupakan sekumpulan metode di mana aktivitas pengajaran dilaksanakan secara terpisah dari aktivitas belajar, (Uno, 2007). Kegiatan belajar mengajar dilakukan dari tempat yang berbeda, yang menjadi medianya adalah internet. Lebih lanjut (Uno, 2007) menyampaikan bahwa dalam pembelajaran jarak jauh berbasis web paling tidak memiliki beberapa unsur a) Membangun pusat kegiatan mahasiswa, yang akan menjadi sarana mahasiswa untuk menambah kemampun, memperoleh dan membaca materi kuliah, dan juga dapat menjadi pusat informasi, b) Adanya interaksi dalam group, mahasiswa berinteraksi satu sama lain dan mendiskusikan materi dalam group. Kehadiran guru dalam grup sekedar memberi penjelasan tentang materi yang diberikan, c) Adanya sistem administrasi mahasiswa, hal ini guna menunjang berbagai aktivitas mahasiswa termasuk memperoleh dan melihat informasi mengenai status mahasiswa, d) Adanya pendalaman materi dan ujian, e) Perpustakaan digital, berfungsi sebagai penunjang dalam bentuk data base, f) Ada materi tambahan dari sumber online untuk menunjang perkuliahan dan memperkaya bahan referensi.

Pada pelaksanaan pembelajaran jarak jauh memiliki syarat minimal yang harus dipenuhi, seperti dapat menggunakan teknologi informasi dan komunikasi (TIK). Syarat ini tentu tidak semua mahasiswa dan dosen mengerti, sehingga harus belajar secara cepat agar proses belajar mengajar dapat berjalan baik. Infrastruktur digital ketersediaannya harus merata karena hal tersebut merupakan syarat mutlak dalam pembelajaran jarak jauh. Belum lagi soal literasi digital dosen dan mahasiswa yang tidak merata akan berpengaruh dalam penggunaan TIK sebagai tool utama dalam proses pembelajaran jarak jauh. Sebab tidak semua dosen dan mahasiswa memiliki kemampuan yang sama dalam menggunakan TIK, ada dosen dan mahasiswa yang sudah terbiasa dan ada juga yang butuh adaptasi.

Selain dosen, mahasiswa dan TIK, faktor lain yang mempengaruhi efektivitas dalam pembelajaran jarak jauh diantaranya adalah media yang digunakan, materi pembelajaran, model pembelajaran, dan metode pe mbelajaran. Ciri-ciri keefektivan pembelajaran adalah berhasil mengantarkan siswa mencapai tujuan instruksional pembelajaran, memberikan pengalaman belajar yang aktraktif, melibatkan siswa secara aktif sehingga menunjang pencapaian tujuan instruksional dan memiliki sarana yang menunjang proses belajar mengajar, (Rohmawati, 2015). Hal tersebut sejalan dengan keinginan mahasiswa Ubhara Jaya, 86,9\% menginginkan dilibatkan diawal perkuliahan untuk secara bersama-sama merancang model perkuliahan agar tidak membosankan. 
Pandemi Covid 19 telah merubah cara perkuliahan, sementara dibanyak kampus termasuk Ubhara Jaya belum terbiasa dengan cara tersebut. Perubahan cara pembelajaran tentu membawa konsekuensi tersendiri dalam prosesnya. Setidaknya kesiapan dosen dan mahasiswa, soal efektivitas pembelajaran jarak jauh, kegamangan dan kesulitan mahasiswa memahami materi kuliah karena pembelajaran jarak jauh lebih pada satu arah sehingga mahasiswa sulit melakukan pendalaman materi kuliah yang disampaikan dosen.

Efektivitas pembelajaran salah satu ukurannya adalah tercapaianya tujuan pembelajaran, sebagaimana disampaikan (Miarso, 2004), bahwa efektivitas pembelajaran merupakan salah satu standar mutu pendidikan dan seringkali diukur dengan tercapainya tujuan, atau dapat diartikan sebagai ketepatan mengelola situasi "do the right things". Efektivitas pembelajaran daring hanya pada mata kuliah teori saja sedangkan mata kuliah praktek dan mata kuliah lapangan tidak efektif jika dilaksanakan secara daring. (Hikmat et al., 2020).

Ada 3 faktor penting lainnya agar efektivitas pembelajaran dapat mencapai tujuan (Leidner \& Jarvenpaa, 1993), yaitu a) Teknologi, cepat dan mudah diakses oleh pembelajar; b) Karakteristik pengajar, bukan teknologinya yang memegang peranan penting dalam efektifvitas pembelajaran, tapi kemampuan pengajar menerapkan instruksional sehingga efektivitas pembelajaran tercapai; c) Karakteristik siswa, perlu diperhatikan bahwa siswa yang tidak memiliki keterampilan dasar dan disiplin lebih cenderung menyenangi belajar tatap muka/konvensional. Sebaliknya siswa yang cerdas, disiplin, dan memiliki percaya diri tinggi lebih mampu mengikuti pembelajaran daring (pembelajaran jarak jauh).

Penelitian dilakukan untuk mengetahui dan mendeskripsikan efektivitas pembelajaran jarak jauh dalam perspektif mahasiswa di Ubhara Jaya yang merupakan pola baru dalam proses belajar mengajar yang sebelumnya dilakukan diruang kelas/tatap muka menjadi daring. Sebab dalam pelaksanaan pembelajaran yang menjadi tujuan utama adalah bagaimana agar mahasiswa dapat menerima pengajaran dengan baik, jangan sampai pembelajaran jarak jauh justru menyulitkan mahasiswa, sehingga tujuan pembelajaran tidak tercapai.

Temuan pada penelitian ini di antaranya, 64,1 \% mahasiswa tidak setuju dengan pembelajaran jarak jauh, berbagai argumentasi disampaikan mahasiswa terhadap pembelajaran jarak jauh, namun secara umum tanggapan mahasiswa karena kurang dapat memahami materi kuliah apalagi jika dosen setiap minggu hanya mengirim materi kuliah dan minta mahasiswa buat tugas. Pola pembelajaran jarak jauh seperti itu membuat mahasiswa bosan dan semakin sulit memahami materi kuliah karena tidak ada kesempatan berdiskusi untuk mendalami materi dengan dosen yang bersangkutan. 35,9\% mahasiswa yang setuju pembelajaran jarak jauh dengan alasan bahwa ini salah satu cara memutus penyebaran pandemi Covid 19. 


\section{Metode Penelitian}

Penelitian ini merupakan penelitian kualitatif. Penelitian kualitatif bermaksud untuk memahami fenomena tentang apa yang dialami oleh subjek penelitian misalnya perilaku, persepsi, motivasi, tindakan dan lain-lain, secara holistik, dan dengan cara deskripsi dalam bentuk kata-kata dan bahasa, pada suatu konteks khusus yang alamiah dengan memanfaatkan berbagai metode alamiah. (Moleong, 2011). Pengumpulan data menggunakan metode survey deskriptif. Survey deskriptif, yaitu suatu metode penelitian yang dilakukan dengan tujuan untuk membuat gambaran atau deskripsi tentang suatu keadaan secara objektif. Penelitian ini dilakukan dengan langkah-langkah pengumplan data, klasifikasi, pengolahan/analisis data, membuat kesimpulan dan membuat laporan. (Notoatmodjo, 2010). Penelitian dilakukan di kampus dua (2) Universitas Bhayangkara Jakarta Raya.

\section{Hasil dan Pembahasan}

Perubahan pola belajar dari tatap muka menjadi daring memberi efek kejut bagi mahasiswa, sebab apa yang dipahami oleh mahasiswa tentang belajar adalah interaksi langsung dalam ruang kelas antara mahasiswa dan dosen. Pemahaman mahasiswa mengenai proses belajar sejalan dengan apa yang disampaikan (Darmayanti et al., 2007), bahwa konsep pembelajaran di perguruan tinggi selalu digambarkan melalui pertemuan tatap muka antara dosen dan mahasiswa yang berlangsung di dalam ruang kuliah atau di dalam kelas. Kelas, dalam konteks ini, memiliki makna sebagai sebuah tempat di mana dosen dan mahasiswa bertemu secara tatap muka di dalam satu ruang yang sama. Karena Pandemi Covid 19, maka metode pembelajaran berubah yakni pembelajaran jarak jauh. Pola pembelajaran jarak jauh merupakan proses pembelajaran dimana tidak terjadi kontak atau tatap muka langsung di dalam kelas antara pembelajar dan pengajar. Proses belajar mengajar terjadi dua arah melalui internet, video, media, televisi, radio, komputer, telepon, dan sebagainya. (Yerusalem et al., 2015). Pembelajaran jarak jauh didesain untuk melayani dan memudahkan siswa atau mahasiswa menerima pelajaran dimanapun berada terutama di masa Covid 19. Walau demikian, banyak mahasiswa yang tidak setuju dengan proses belajar mengajar jarak jauh.

Penelitian ini menemukan $64,1 \%$ tidak setuju dengan pembelajaran jarak jauh. Sebab, pembelajaran jarak jauh, mahasiswa merasa kurang dapat memahami materi perkuliahan apalagi dilakukan dengan komunikasi satu arah sehingga sulit mendalami materi kuliah. Bagi mahasiswa, meski menguntungkan tetapi lebih suka belajar di kelas karena bisa ketemu dosen dan dapat secara langsung bertanya jika ada materi kuliah yang belum dipahami. Temuan lainnya, mahasiswa jadi malas belajar dan sulit memahami materi yg diberikan oleh dosen Walau demikian, 35,9\% yang menyatakan setuju dengan alasan bahwa ini salah satu cara memutus penyebaran pandemi Covid 19, dan belajar dapat lebih santai karena dapat dilakukan dirumah atau dimana saja.

Ketidak-setujuan mahasiswa dengan pembelajaran jarak jauh disebabkan beberapa hal a) Kurangnya interaksi antara guru/dosen dan siswa/mahasiswa, maupun siswa/mahasiswa 
dengan siswa/mahasiswa; b) Mengabaikan aspek akademik dan aspek sosial; c) Proses belajar mengajar cenderung ke arah pelatihan dari pada pendidikan; d) Berubahnya peran guru dari yang semula menguasai teknik pembelajaran konvensional, kini dituntut mengetahui teknik pembelajaran menggunakan ICT; e) Siswa/mahasiswa yang tidak memiliki motivasi belajar cenderung gagal; f) Tidak semua daerah (terutama di Indonesia) tersedia jaringan Internet; dan g) Kurang tenaga kerja pendidikan yang mengetahui dan memiliki keterampilan internet. (Sagita \& Nisa, 2019).

Pola belajar jarak jauh tentu saja memiliki kelebihan dan kekurangan. Penelitian ini menemukan kelebihan dan kekurangan pembelajaran jarak jauh. Kelebihan diantaranya mengurangi dampak Covid-19; dalam situasi pandemi cara paling tepat untuk kegiatan belajar mengajar melalui daring; materi kuliah dapat dipelajari secara berulang oleh mahasiswa; mampu membangun kemandirian mahasiwa dalam belajar; efisien dalam waktu dan biaya dan mahasiswa dapat mengikuti perkuliahan dan mengerjakan tugas dimana saja walaupun sambil kerja

Kekurangan dari pendidikan jarak jauh, diantaranya sulit memahami materi kuliah; tugas yang di berikan terkadang terlalu banyak, dan waktu pengumpulan terlalu cepat; mahasiswa jadi malas untuk belajar; diskusi kelompok kurang efektif; dan dosen mengajar seadanya dan terkadang hanya memberi materi kuliah tanpa penjelasan.

Temuan penelitian di atas sejalan dengan temuan penelitian yang dilakukan oleh (Pulungan et al., 2021) bahwa dalam pembelajaran daring atau jarak jauh memiliki kelebijan dan kekurangan. Banyak kerugian yang diakibatkan oleh pandemic covid 19, dan akibatnya telah dirasakan oleh masyarakat, walau demikian, ada sisi baik yang dapat dijadikan pelajaran dan bermanfaat terutama pada dunia pendidikan yang merubah cara lama dalam belajar seperti tatap muka menjadi sistem online. Pola belajar yang baru ini dapat dilakukan dengan beberapa pilihan. Model pembelajaran dapat dilakukan dengan full online dan juga dengan pola hybrid dimana tidak semua pembelajar hadir dikelas namun tetap dapat mengikuti proses belajar dari mana saja dengan sistem online.

Hasil penelitian menunjukkan kelebihan dari kegiatan pembelajaran secara daring, antara lain mahasiswa merasa lebih santai serta senang; mahasiswa merasa memiliki lebih banyak waktu dirumah bersama keluarganya; mahasiswa merasa memiliki lebih banyak waktu istirahat serta bersantai; dan mahasiswa merasa tidak tegang. Sedangkan kekurangan yang dirasakan, diantaranya mahasiswa merasa boros disebabkan kuota jadi cepat habis; mahasiswa merasa lebih susah menguasai pelajaram yang di informasikan oleh dosen; mahasiswa merasa uang jajanan yang didapatkan berkurang; dan mahasiswa merasa aktivitas sosial dengan teman- temanya terhambat.

Selama masa Pandemi Covid 19, segala aktivitas yang melibatkan banyak orang dibatasi termasuk dalam pembelajaran. Universitas Bhayangkara Jakarta Raya (Ubhara Jaya), salah satu institusi penyelenggara pendidikan tinggi mengambil kebijakan pembelajaran jarak jauh dengan menggunakan e-learning. Penggunaan e-learning sebagai media belajar bagi 
mahasiswa Ubhara Jaya mendapat respon cukup baik, 52,9\% mahasiswa setuju. Mahasiswa menyadari bahwa ini salah satu upaya memutus menyebaran Covid 19. Dengan e-learning, materi yang diberikan dosen dapat dipelajari secara berulang. Materi yang diajarkan juga telah tersedia dalam e-learning sehingga mahasiswa bisa belajar dimana saja dan kapan saja, mahasiswa antusias dalam mengerjakan tugas karena pengerjaan tugas dan pengumpulan tugas dilakukan secara online sehingga menjadi efektif dan menghemat biaya pengeluaran akibat pengerjaan tugas, (Abi Yodha et al., 2019).

Penggunaan elearnig dalam proses belajar mengajar tidak memiliki manfaat dan kelemahan. Manfaat menggunakan elearning, Waktu dan tempat belajar fleksibel; 2. Adanya kebebasan untuk memutuskan kapan akan mulai belajar dan bagian dari modul mana yang akan dipelajari dan dikerjakan maupun diselesaikan terlebih dahulu sangat tergantung dari pembelajar itu sendiri yakni siswa atau mahasiswa. Bahkan jika mengalami kesulitan dalam belajar dapat mengulangi sampai benar-benar bisa memahaminya; 3. Belajar dengan menggunakan elearning dapat mengurangi pengeluaran karena tidak perlu ke sekolah atau kekampus sehingga biaya perjalanan ataupun biaya akomodasi lainnya dapat dihemat. Termasuk sekolah ataupun kampus dapat menghemat pengeluaran jika belajar secara tatap muka; 4. Modul atau materi yang telah dikirim dapat dipelajari secara berulang olah siswa atau mahasiswa; dan 5. Proses administrasi dalam belajar mengajar berjalan secara otomatis. (Yudhana \& Kusuma, 2021).

Walau demikian, proses belajar mengajar menggunakan elearning memiliki kekurangan. Walaupun demikian pemanfaatan elearning juga tidak terlepas dari berbagai kekurangan, diantaranya interaksi antara pembelajar dan pengajar atau antara siswa/mahasiswa dengan guru atau dosen bahkan antara siswa dan mahasiswa dengan sesamanya terbatas. Hal ini tentu saja memperlambat atau bahkan menghilangkan terbentuknya sebuah nilai yang dibutuhkan oleh setiap orang yang terlibat dalam proses belajar mengajar. Pengunaan elearning memiliki kecenderungan mengecilkan aspek akademik sebab proses belajar mengajar yang dilakukan sekedar menggugurkan kewajiban bahkan mengarah kepada komersialisasi. Proses tersebut juga mendorong tergerusnya aspek sosial dalam dunia pendidikan. Belajar mengajar lebih terasa seperti pelatihan daripada sebuah proses pendidikan. (Yuliana, 2020).

Terkait pemahaman materi yang dikirim melalui e-learning secara umum mahasiswa dapat memahami. Temuan pada penelitian ini, 50,3\% mahasiswa menjawab dapat memahami sebab dosen dalam menyampaikan materi sering disertai dengan contoh kasus dan langsung pada intinya. Namun demikian, 49,7\% tidak dapat memahami, terutama pada materi baru yang masih butuh penjelasan. Kesulitan memahami materi seringkali disebabkan gangguan signal yang tidak stabil sehingga ketinggalan pemaparan dosen. Pada konteks ini pengajar dituntut tidak hanya mengirim materi, namun juga disertai penjelasannya. Selain itu, memberi kesempatan kepada mahasiswa untuk berdiskusi dengan dosen atau antar sesama mahasiswa untuk mendalami materi perkuliahan. Sejalan dengan hal tersebut, $72,5 \%$ mahasiswa 
menjawab tidak memperoleh pengetahuan yang diharapkan dalam proses belajar mengajar, dan 27,5\% menjawab mendapatkan pengetahuan yang cukup dari pembelajaran jarak jauh.

Dalam proses belajar mengajar terutama di masa Pandemi Covid 19 yang dilaksanakan secara daring, dibutuhkan pola pembelajaran yang tidak membosankan. Untuk itu penting melibatkan mahasiswa di awal perkuliahan dalam merancang pola belajar antara dosen dan mahasiswa. 86,9\% mahasiswa menjawab perlu dilibatkan untuk menghindari perkuliahan yang membosankan dan satu arah.

Sejak Virus Covid 19 makin luas, hampir semua kegiatan dibatasi dan dilakukan dari rumah, salah satunya adalah proses perkuliahan. Mahasiswa belajar melalui e-learning yang dimana setiap mata kuliah dapat diakses oleh mahasiswa dari rumah. Tentu hal ini berefek pada pengeluaran mahasiswa karena tidak perlu mengeluarkan biaya seperti jika kegiatan perkuliahan dilakukan di kampus. Namun, penelitian ini menemukan, 43,8 \% menjawab tidak, artinya pengeluaran mahasiswa dengan belajar dirumah tidak lebih hemat dibandingkan dengan kuliah di kampus, karena tetap mengeluarkan biaya membeli kuota, earphone atau headset. Sedangkan yang menjawab pengeluaran berkurang yakni $41,8 \%$ mahasiswa. Dan sisanya $14,4 \%$ menjawab sama saja. Temuan ini menjelaskan bahwa belajar dari rumah tidak memberi efek hemat pada pengeluaran mahasiswa.

Dalam belajar dengan sistem pembelajaran jarak jauh seringkali tidak terlaksana sebagaimana yang seharusnya karena terkendala beberapa hal, salah satu kendala yang diungkapkan mahasiswa selama pembelajaran jarak jauh, adalah tidak stabilnya jaringan, me nyebabkan kuliah online ikut terganggu. Penggunaan media internet/e-learning memiliki kendala yang cukup besar, koneksi jaringan dan kesalahan teknis seperti server down and error menghambat keberhasilan pembelajaran, (Nurmukhametov et al., 2015).

Selain itu beberapa mahasiswa telat mengirim tugas bahkan tidak mengirim tugas sama sekali, tentu hal tersebut mempengaruhi nilai tugas, akibatnya mahasiswa mendapat nilai rendah bahkan tidak lulus pada mata kuliah yang diambil. 43,1\% menjawab kalau jaringan menjadi kendala selama pembelajaran jarak jauh. Sementara $37,3 \%$ menjawab tidak mengalami gangguan. Sementara 19,6\% menjawab kadang-kadang saja mengalami gangguan. Pada proses belajar mengajar melalui pembelajaran jarak jauh, seringkali ditemukan kendala ataupun ketidaksesuaian dengan pembelajaran yang seharusnya, banyak yang mengira tanggung jawab pengajar dalam melaksanakan pembelajaran jarak jauh jauh lebih ringan ketimbang dengan pembelajaran tradisional, (Semradova \& Hubackova, 2016).

\section{Kesimpulan}

Secara umum atau 64,1\% mahasiswa tidak setuju dengan pembelajaran jarak jauh karena menganggap tidak efektif dan lebih memilih belajar tatap muka. Mahasiswa merasa kurang dapat memahami materi yang disampaikan dosen dan banyak kendala dalam proses pembelajaran salah satunya adalah tidak stabilnya signal sehingga penjelasan dosen sering kali sulit didengarkan dan dimengerti. Kesulitan dalam memahami materi kuliah karena 
gangguan signal menemukan bahwa $72,5 \%$ mahasiswa menyatakan tidak memperoleh pengetahuan yang mereka harapkan. Namun, belajar dengan menggunakan e-learning, 52,9\% mahasiswa setuju. Mahasiswa berpendapat bahwa belajar dengan menggunakan e-learning salah satu sumbangsi mahasiswa dalam upaya memutus rantai penyebaran Covid 19. Selain itu materi telah tersedia sehingga dapat dipejari secara berulang, dimanapun dan kapanpun. Selanjutnya, materi pembelajaran yang dikirim di e-elearning, 50,3\% mahasiswa dapat memahaminya, karena dosen biasanya menyertakan contoh agar mahasiswa dapat lebih mudah memahaminya. Mengenai pengeluaran mahasiswa selama pembelajaran jarak jauh, 43,8\% mahasiswa menjawab bahwa pengeluaran tidak lebih hemat. 41,8\% menjawab pengeluaran berkurang, dan 14,4\% menyatakan sama saja sebelum dan selama covid 19 . Kendala utama yang dirasakan mahasiswa selama pembelajaran jarak jauh adalah tidak stabilnya signal, 43,1\% menyatakan jaringan menjadi kendala utama, sehingga beberapa mahasiswa sering telat mengirim tugas bahkan dianggap tidak hadir dalam perkuliahan yang akhirnya berimbas pada penilaian akhir dosen. Walau demikian, 37,3\% mahasiswa menjawab tidak mengalami gangguan sama sekali, dan 19,6\% menjawab kadang-kadang saja mengalami gangguan.

\section{Ucapan Terima Kasih (Opsional)}

Secara khusus penulis sampaikan terimakasih kepada: 1) Rektor Universitas Bhayangkara Jakarta Raya (Ubhara Jaya), Irjen. Pol. (Purn) Dr. Drs. H. Bambang Karsono, S.H., M.M. yang senantiasa mendorong dan memberi semangat kepada para dosen untuk terus melakukan tri dharma perguruan tinggi; 2) Dekan Fakultas Ekonomi dan Bisnis Ubhara Jaya, Dr. Istianingsih, M.S.Ak., CA., CSRS., CSRA., CMA., CBV; 3) Para Dekanat, Kaprodi dan Sekretaris Prodi Manajemen Ubhara Jaya, serta rekan sejawat dosen FEB Ubhara Jaya; 4) Ucapan terimakasih penulis juga sampaikan kepada pengelola Jurnal Kajian IImiah (JKI) Ubhara Jaya; dan 5) Mahasiswa Ubhara Jaya yang telah berpartisipasi dalam menjawab pertanyaan-pertanyaan penulis saat melakukan pengumpulan data penelitian ini.

\section{Daftar Pustaka}

Abi Yodha, S., Abidin, Z., \& Adi, E. P. (2019). Persepsi Mahasiswa Terhadap Pelaksanaan Elearning Dalam Mata Kuliah Manajemen Sistem Informasi Mahasiswa Jurusan Teknologi Pendidikan Universitas Negeri Malang. Jurnal Kajian Teknologi Pendidikan, 2(3), 181187.

Darmayanti, T., Setiani, M. Y., \& Oetojo, B. (2007). E-learning Pada Pendidikan Jarak Jauh: Konsep Yang Mengubah Metode Pembelajaran di Perguruan Tinggi di Indonesia. Jurnal Pendidikan Terbuka Dan Jarak Jauh, 8(2), 99-113.

Hikmat, H., Hermawan, E., Aldim, A., \& Irwandi, I. (2020). Efektivitas Pembelajaran Daring Selama Masa Pandemi Covid-19: Sebuah Survey Online. LP2M.

Kemenkes RI. (2021). Situasi Terkini Perkembangan Coronavirus Disease (COVID-19). Kemenkes, 1-4. https://covid19.kemkes.go.id/download/Situasi_Terkini_050520. (Diunduh 3 Oktober 2021)

Leidner, D. E., \& Jarvenpaa, S. L. (1993). The information age confronts education: Case studies on electronic classrooms. Information Systems Research, 4(1), 24-54. 
Miarso, Y. (2004). Menyemai Benih Teknologi Pendidikan. Kencana.

Moleong, L. J. (2011). Metodologi Penelitian Kualitatif, cetakan XXIX. Bandung: PT. Remaja, Rosdakarya.

Notoatmodjo, S. (2010). Metodologi Penelitian Kesehatan Notoatmodjo S, editor. Jakarta: PT. Rineka Cipta.

Nurmukhametov, N., Temirova, A., \& Bekzhanova, T. (2015). The Problems of Development of Distance Education in Kazakhstan. Procedia-Social and Behavioral Sciences, 182, 15-19.

Pengelola web kemdikbud. (2020). SE Mendikbud BOS.

Pengelola web Kemdikbud. (2020). Kemendikbud Terbitkan Pedoman Penyelenggaraan Belajar dari Rumah. In Jakarta, 28 Mei 2020.

Pulungan, R., br Ginting, L. S. D., \& Nasution, A. S. (2021). Kelebihan Dan Kekurangan ELearning Berdasarkan Pengalaman Mahasiswa Umn Al Washliyah. Prosiding Seminar Nasional Hasil Penelitian, 4(1), 504-507.

Rohmawati, A. (2015). Efektivitas Pembelajaran. Jurnal Pendidikan Usia Dini, 9(1), 15-32.

Sagita, M., \& Nisa, K. (2019). Pemanfaatan E-learning Bagi Para Pendidik Di Era Digital 4.0. Jurnal Sosial Humaniora Sigli, 2(2), 35-41.

Semradova, I., \& Hubackova, S. (2016). Teacher Responsibility in Distance Education. Procedia-Social and Behavioral Sciences, 217, 544-550.

Uno, H. B. (2007). Model pembelajaran menciptakan proses belajar mengajar yang kreatif dan efektif. Jakarta: Bumi Aksara.

Yerusalem, M. R., Rochim, A. F., \& Martono, K. T. (2015). Desain dan Implementasi Sistem Pembelajaran Jarak Jauh Di Program Studi Sistem Komputer. Jurnal Teknologi Dan Sistem Komputer, 3(4), 481-492.

Yudhana, A. S. L., \& Kusuma, W. A. (2021). Kelebihan dan Kekurangan Pembelajaran Jarak Jauh Atau E-Learning dan Learning Management System (LMS) Menggunkan Pendekatan Literature Review, dan User Persona. Jurnal Syntax Admiration, 2(9), 16171628.

Yuliana, Y. (2020). Analisis Keefektivitasan Pemanfaatan E-learning Sebagai Media Pembelajaran Pendidikan Agama Islam Pada Masa Pandemi Corona (Covid-19). SALAM: Jurnal Sosial Dan Budaya Syar-I, 7(10), 875-894. 